\title{
Ex situ Conservation Effort through the Inventory of Plant Diversity in Mount Seblat, Bengkulu
}

\author{
${ }^{\square}$ Imawan Wahyu Hidayat, Ikhsan Noviady, Yati Nurlaeni
}

DOI: 10.15294/biosaintifika.v9i3.9668

Cibodas Botanical Garden, Indonesian Institute of Sciences, Indonesia

\section{History Article}

Received 9 May 2017

Approved 18 October 2017

Published 31 December 2017

\section{Keywords}

Ex situ plants conservation; Mount Seblat; Plant diversity

\begin{abstract}
Mount Seblat, as part a of Kerinci Seblat National Park (KSNP), is a pristine and natural mountain, particularly from disturbances and destructions by human activities. Nevertheless, the richness of biological resources especially plant diversity.in this area has not been more explored. The purpose of this study was to conduct an inventory of plant diversity and to determine the plant species composition. The inventory activities were conducted by plants collection along the ascent route. The results were then be maintained through ex situ conservation method in Cibodas Botanical Garden (CBG). The study was conducted by exploratory method, from Seblat Ulu Village ( $641 \mathrm{~m}$ asl) up to altitude of $1,037 \mathrm{~m}$ asl. There were 18 points of plant sample observation with an area of 5 x 5 square meters per point. Plant collection obtained 380 specimens. Five groups of most collected plants were Lauraceae (18 species), Rubiaceae ( 8 species), Anacardiaceae (6 species), Annonaceae (5 species), and Fagaceae (4 species). In order to enrich the plants collection as well as conduct the ex situ conservation effort, plants from Orchidaceae were also collected which resulted in 33 species. These results were an important initial inventory of plant diversity of Mount Seblat, considering that there was no record as well as very limited current information. When the environment disturbance tends to increase, this information may act as a reference and an initial database to develop plants conservation effort and strategy in the future.
\end{abstract}

\section{How to Cite}

Hidayat, I. W., Noviady, I., \& Nurlaeni, Y. (2017). Ex situ Conservation Effort through the Inventory of Plant Diversity in Mount Seblat, Bengkulu. Biosaintifika: Journal of Biology \& Biology Education, 9(3), 513-522.

(C) 2017 Universitas Negeri Semarang 


\section{INTRODUCTION}

Biodiversity loss and even the decline of flora and fauna in Sumatran region, have apparently generated little interest after decades of warnings by scientists and conservationists, but more recent concerns about the links between climate change, deforestation (van der Werf et al., 2008). These loss of ecosystem services have brought a new focus on forest conservation issues (Laumonier et al., 2010). In 2007, only 29\% of Sumatra Tropical Rain Forest were protected by conservation areas and only nine of the 38 eco-floristic sectors had more than $50 \%$ of their remaining forest cover protected. Furthermore, forest loss has been occurred specifically for submontane, montane and upper montane of central Sumatra as much as $6 \%$ and $4 \%$ (Laumonier et al., 2010).

Nevertheless, mountains in Sumatra were still keeping a wealth of plants diversity of tropical wet highland. One of important protected areas in Central Sumatra was Kerinci Seblat National Park (KSNP). As the largest conservation area in Sumatra, KSNP had an important role in maintaining the quality and quantity of typical flora and fauna of Sumatra which began to degrade. Based on Decree of Minister of Forestry and Plantation No. 901/Kpts-V/1999, KSNP was established as wide as 1.375 million ha. The extent of KSNP was passing through West Sumatra, Jambi, South Sumatra and Bengkulu. However, the park was experiencing new challenges, not only from the tens of thousands of small-scale farmers that illegally growing coffee and other crops inside the park, but also from the 15 district and municipal governments territory (Bettinger, 2014). The establishment of oil palm and timber plantations has now become main drivers of deforestation in Indonesia (Butler et al., 2009; Koh $\&$ Wilcove, 2008). The high profitability of land use for like oil palm, rubber, and forestry plantations for pulp and paper, combined with a environment policy that effectively subsidizes such land uses increases the opportunity costs of conserving tropical forests (Cacho et al., 2014).

Within extraordinary pressures to the conservation areas existence, it is necessary to carry out immediate efforts in conservation sector, one of them is ex situ conservation. Ex situ conservation should be placed as important part of conservation efforts. These due to the extant habitats of a growing number of species are becoming less available for their survival for a variety of reasons, including global warming, disease, drought, fragmentation, and deforestation (Braverman, 2014).
To maintain many species, an alternative habitat (or the existing one) might be (re)constructed and managed (Braverman, 2014). Moreover, ex situ plant collections would help to conserve threatened species (Richards et al., 2007), function as a source of traits for agricultural improvement (Brummer et al., 2011; Neale \& Kremer, 2011), or has been used to propagate large numbers of plant individuals for ecosystem restoration or assisted migration (Broadhurst $e t$ al., 2008; Vitt $e t$ al., 2010; Aitken \& Whitlock, 2013).

In accordance with its duties and functions, Cibodas Botanical Garden (CBG)-Indonesian Institute of Sciences (LIPI) had an obligation to perform the ex situ conservation efforts, especially for the types of plants from tropical wet highlands zone. This was consistently with the Decree of the Chairman of LIPI dated January $17^{\text {th }}$, 1987, No.25/KEP/D.5./87, Cibodas Botanical Garden had the task to carry out the exploration activities and plants conservation from tropical wet highlands. In the last five years, CBG routinely conducts exploration activities and plants collection as a part of ex situ conservation, with a focus on the mountains of Sumatra. In 2015, the exploration activities and plants collection by $e x$ situ conservation was conducted in Mount Seblat, Bengkulu. Therefore, this paper would discuss the activities of exploration and plants collection in Mount Seblat. The purposes of study were to conduct an inventory of plant diversity in Mount Seblat and to collect local characteristics of wild living plants specimen, and which later be maintained and proliferated in CBG. The results were expected to become an important initial inventory of plants diversity of Mount Seblat, considering that there was no such a record as well as very limited current information. When the environment disturbance tends to increase, these informations may be a reference and an initial database to develop plants conservation efforts and strategy in the future.

\section{METHODS}

The study was conducted in Mount Seblat, as a part of KSNP, with starting point began from Seblat Ulu Village side. Exploration area was along the tracking path to the Mount Seblat summit on range of $2^{\circ} 55^{\prime} 41.8^{\prime \prime} \mathrm{S}-2^{\circ} 56^{\prime} 32.4^{\prime \prime} \mathrm{S}$ and $102^{\circ} 6^{\prime} 13.6^{\prime \prime} \mathrm{E}-102^{\circ} 6^{\prime} 55.9^{\prime \prime} \mathrm{E}$ (Figure 1). The highest location of the exploration was at 1,037 $\mathrm{m}$ above sea level. The terrain along the tracking path was dominated by steep slopes, typical of mountainous terrain. As a part of the national park, it might be obvious that the diversity of 
its species was still relatively high, both vertical and horizontal. Nevertheless, it still can be found some trails of illegal logging includes the wooden blocks scattered and cutted trees. Seblat Ulu Village was located at the southern side of KSNP, which administratively including to Pinang Belapis District, Regency of Lebong, Bengkulu Province. The village was directly adjacent to KSNP border with about two hundred families. Livelihood of resident was dominated by work on agriculture sector, such as paddy field, coffee, coconut and oil palm. Some people were also raised livestock such as cow, goat and fowl.

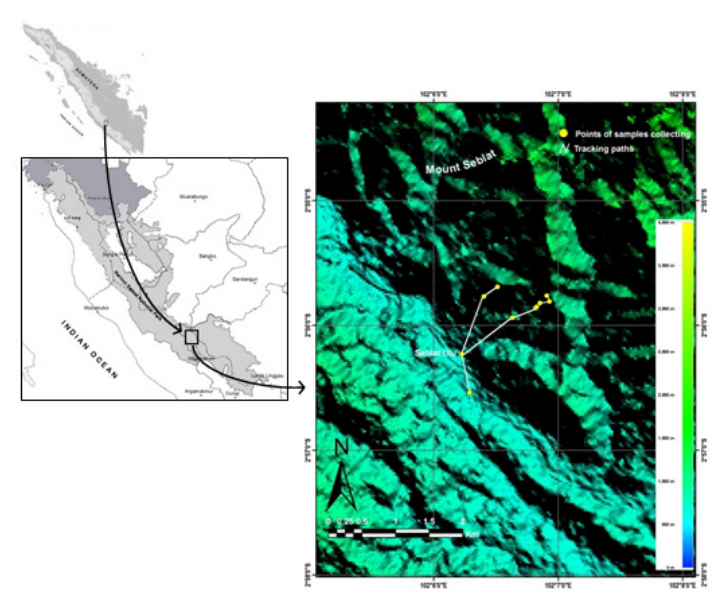

Figure 1. Range area of exploration at Mount Seblat, Bengkulu, with the tracking path and points of plant samples collection. (Coordinate system: UTM projection, zone 48S, datum WGS84).

Field activities were conducted in 13-30 April 2015. Exploration activities and plants inventory were carried out by the explorative method (Partomihardjo \& Rahajoe, 2004) to collect information about plants. Explorative method was conducted by tracking the forest through existing path and/ or creates new pathways. The plants data collected were included habitats, morphological character and other supporting data (such as soil pH, temperature and humidity). The points of sampling sites and plants collection were shown in Figure 1. Details of exploration activities and research were as follow:

Plants collection was an activity of taking plant materials both seedlings, cuttings or seeds of plants, from the origin habitat, which would later be re-planted and breed at CBG. List of priority plants to collect from the field obtained from: 1) literature study, 2) inventory and recommendations from the nursery and registration unit of CBG, 3) consultation with the Research Center of Biology - LIPI, 4) and the recommendations of the Ministry of Forestry and Environment.
Nevertheless, it was possible to collect unlisted plant, given that the plant was found and collected meets the requirements of priority plants in CBG (e.g. unique, endangered, and had a high potential value of economic, ethnobotany, ornamental, development of science, or other value).

In detail, the activities of plants collection consist of collecting plants from their natural habitat with priority requirements were endemic plants of tropical wet highlands, unique, endangered, and have a high potential value. It was also conducted data recording of micro-habitat of plants which used as a reference in the acclimatization and re-planting plants in CBG. Points of plants collection were determined randomly (Figure 1), along the tracking path to the mount summit. There were 18 points of plants collection and observation with an area of $5 \times 5$ square meters per point. When there was an area with a high sunlight intensity, the area that overgrown with large number of priority plants, then the data collection area were expanded within a radius of approximately five meters.
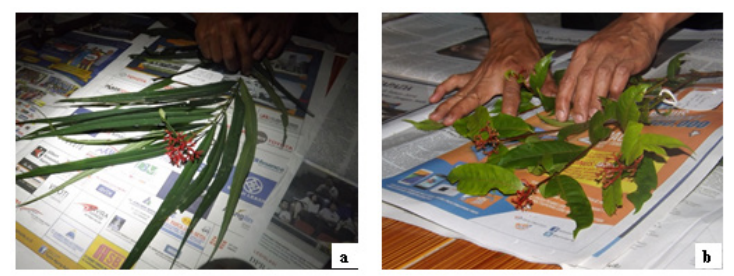

Figure 2. Making a herbarium on the field: (a) lay outing of plants with a complete organ which would be made an herbarium; (b) plant specimen placed in a paper included supporting information (such as species name, elevation, collector and date) to facilitate handling and further identification. (Photographs by: Ikhsan Noviady).

Making the herbaria aimed to document the types of plants which exist at the field, part of plants identification for unknown/ unidentified species, and to enrich the herbarium collection of Cianjur Hortus Tjibodasensis (CHTJ). Plant specimens that would be made as a herbarium should consist of a complete organ: trunk, branches, leaves, flowers (and/ or fruit), with dimensions of $30 \times 40 \mathrm{~cm}^{2}$ (Figure 2).

In order to ensure the survivorship of plants collection, the intensive maintenance was conducted after the plants were arrived at CBG. Watering, fertilizing, vitamin administration and pest control were routinely performed regularly, either daily or weekly. Furthermore, the observation of the plants survivorship level was also performed. Survivorship level $\left(l_{x}\right)$ is showing the 
number or proportion of individuals surviving to each age (time unit) for a given individual or group. Survivorship level $\left(l_{x}\right)$ is obtained by formula, which is the initial number of individual at early time, and is the number of survived individual in selected range of $x$ time unit.

$$
l_{x}=n_{x} / n_{0} ; x=0,1,2, \ldots k
$$

Crude death rate $\left(d_{x}\right)$, which measures the number of individuals which die within age category $x$.

$$
d_{x}=n_{x}-n_{x+1} ; \sum_{i=0}^{k} d_{i}=n_{0}
$$

Proportional death rate, or "risk" $\left(q_{x}\right)$ which measures the proportion of individuals surviving at the beginning of age category $(x)$ which the died within that category.

$$
q_{x}=\frac{d_{x}}{n_{x}}=\frac{n_{x}-n_{x-1}}{n_{x}} ; q_{k-1}=1
$$

It is common to study survivorship as a semi-log plot of $l_{x}$ and $x$, known as a survivorship curve.

\section{RESULTS AND DISCUSSION}

\section{Taxonomic diversity and plants collection}

Plants diversity in sub-montane to montane zone of Mount Seblat ( $800 \mathrm{~m}$ to $1,000 \mathrm{~m}$ asl) was remarkable. Totally, there were 380 specimens collected from field site, either live (seedling, seeds and cutting) or in form of herbaria. There were noted at least 48 families (and 3 specimens unidentified) of plants collected, with distribution patterns follow the elevation which then being interesting to be studied.

In addition, beside typical plants of the tropical wet highland, in Mount Seblat had also various species of Sumatran lowland plants, such as family of Dipterocarpaceae. The activities was also collected plants from Orchidaceae and Nepenthaceae. Orchidaceae and Nepenthaceae were plant families with a high conservation value, partly due to its declining numbers and threatening of its existence in their natural habitat. Therefore, both types of plants were used to be "target plants". Furthermore, the detail of plant species, the amount and elevation point where it collected are shown in Table 1.
Furthermore, the herbaria collected were Illicium sp., Illiaceae (1 sheet); Cinnamomum zeylanicum, Lauraceae (1 sheet); Lasianthus sp., Rubiaceae (1 sheet); Parashorea sp., Dipterocarpaceae (1 sheet); Rubiaceae (1 sheet); Sterculia sp., Sterculiaceae (2 sheets); Psychotria sp., Rubiaceae (1sheet). As a note, the diversity such above did not directly reflecting the condition of mountainous forest vegetation in Mount Seblat in general. The plants collected in this study were to be conserved and have to be corresponded with ex situ conservation efforts of CBG (endemic plants typical of tropical wet highlands, unique, endangered, and have a high potential value, or in order to enrich of plants collection in CBG). Moreover, there are some species that have not been identified where in this research were taxonomically named as "sp.", and some were still identified at family level. This condition reveals that future researches especially regarding taxonomic topics are needed to uncover the plant biodiversity taxonomically in natural tropical forest.

\section{Extend distribution}

Flora of Malaya could be distinguished between family of megatherm and microtherm (Sniderman \& Jordan, 2011). Families included to the group of megatherm were predominantly distributed in the tropics, or nearly confined to elevation below $1,000 \mathrm{~m}$ asl. Plant which included in megatherm is a plant that requires a high temperature combined with very abundant moisture for its successful growth. The families from this group are Anacardiaceae, Burseraceae, Capparidaceae, Combretaceae, Connaraceae, Dilleniaceae, Dipterocarpaceae, Flacourtiaceae, Maranaceae, Myristicaceae and Rhizophoraceae. Furthermore, group of microtherm was predominant in temperate regions and a number of genuses which could only be found at an elevation above $1,000 \mathrm{~m}$ asl.

These descriptions were also discovered in Mount Seblat, which Anacardiaceae, Burseraceae, Dipterocarpaceae, Myristicaceae included to megatherm group, where dominantly founded at elevation below $1,000 \mathrm{~m}$ asl. Lauraceae was included to microtherm because some species were found at an elevation over 1,000 $\mathrm{m}$ asl. Sniderman \& Jordan (2011) was also claimed that some families such as Arecaceae, Araucariaceae, Clethraceae, Cunoniaceae, Ericaceae, Fagaceae, Lauraceae, Myrtaceae, Pentaphylaceae, Podocarpaceae, Symplocaceae and Theaceae were better presence in medium and high elevation than in the lowlands. In Mount Seblat, some families such as Ericaceae, Fagaceae, Lauraceae, 
Imawan Wahyu Hidayat et al. / Biosaintifika 9 (3) (2017) 513-522

Table 1. List of plants families and species, amount and elevation where it collected.

\begin{tabular}{|c|c|c|c|c|c|}
\hline \multirow{2}{*}{ Family } & \multirow{2}{*}{ Species } & \multirow{2}{*}{$\begin{array}{c}\text { Amount } \\
\mathrm{n}\end{array}$} & \multirow{2}{*}{ Type of material } & \multicolumn{2}{|c|}{ Elevation (m asl) } \\
\hline & & & & $800-900$ & $>900$ \\
\hline Acanthaceae & Psychotria sp. & 3 & $\mathrm{Pl} ; \mathrm{H}$ & - (2 Pl.) & - $(1 \mathrm{H})$ \\
\hline \multirow[t]{4}{*}{ Anacardiaceae } & Anacardiaceae & 2 & Pl. & & $\bullet(2)$ \\
\hline & Campnosperma sp. & 1 & P1. & & $\bullet(1)$ \\
\hline & Mangifera sp. & 5 & P1. & $\bullet(5)$ & \\
\hline & Semecarpus sp. & 1 & Pl. & & $\bullet$ \\
\hline \multirow[t]{7}{*}{ Annonaceae } & Annonaceae & 5 & P1. & $\bullet(4)$ & $\bullet(1)$ \\
\hline & Artabotrys sp. & 3 & Pl. & • (3) & \\
\hline & Artabotrys suaveolens & 3 & P1. & - $(3)$ & \\
\hline & Goniothalamus sp. & 2 & Pl. & & $\bullet(2)$ \\
\hline & Mezzetha sp. & 2 & Pl. & & $\bullet(2)$ \\
\hline & Orophea sp. & 3 & Pl. & & $\bullet(3)$ \\
\hline & Popowia pisocarpa & 2 & P1. & & $\bullet(2)$ \\
\hline \multirow[t]{2}{*}{ Apocynaceae } & Apocynaceae & 1 & Pl. & & $\bullet(1)$ \\
\hline & Planchonella vallida & 2 & Pl. & & • $(2)$ \\
\hline Araceae & Alocasia sp. & 5 & P1. & & $\bullet(5)$ \\
\hline \multirow[t]{2}{*}{ Arecaceae } & Licuala sp. & 2 & P1. & & $\bullet(2)$ \\
\hline & Pinanga sp. & 22 & P1.; S & • (1 Pl.; $10 \mathrm{~S})$ & - $(1 \mathrm{Pl} . ; 10 \mathrm{~S})$ \\
\hline Asteraceae & Vernonia arborea & 2 & Pl. & & $\bullet(2)$ \\
\hline Bignoniaceae & Bignoniaceae & 1 & Pl. & & $\bullet(1)$ \\
\hline Burseraceae & Canarium sp. & 5 & Pl. & $\bullet(1)$ & $\bullet(4)$ \\
\hline Celastraceae & Euonymus sp. & 2 & Pl. & $\bullet(2)$ & \\
\hline \multirow[t]{4}{*}{ Clusiaceae } & Calophyllum sp. & 5 & Pl. & • (3) & $\bullet(2)$ \\
\hline & Clusiaceae & 2 & Pl. & & $\bullet(2)$ \\
\hline & Garcinia rostrata & 2 & Pl. & & $\bullet(2)$ \\
\hline & Garcinia sp. & 2 & Pl. & $\bullet(2)$ & \\
\hline Cornaceae & Mastixia trichotoma & 4 & Pl. & $\bullet(4)$ & \\
\hline Dipterocarpaceae & Parashorea sp. & 6 & Pl. & $\bullet(3)$ & $\bullet(3)$ \\
\hline \multirow[t]{3}{*}{ Ebenaceae } & Diospyros buxifolia & 1 & Pl. & $\bullet(1)$ & \\
\hline & Diospyros sp. & 4 & $\mathrm{Pl}$. & & $\bullet(4)$ \\
\hline & Polyalthia sp. & 2 & Pl. & & $\bullet(2)$ \\
\hline \multirow[t]{2}{*}{ Elaeocarpaceae } & Elaeocarpus hayate & 1 & P1. & & $\bullet(1)$ \\
\hline & Elaeocarpus sp. & 1 & Pl. & & $\bullet(1)$ \\
\hline \multirow[t]{2}{*}{ Ericaceae } & Rhododendron sp. & 7 & $\mathrm{Pl}$. & • (7) & \\
\hline & Vaccinium sp. & 2 & Pl. & $\bullet(2)$ & \\
\hline \multirow[t]{2}{*}{ Euphorbiaceae } & Croton argyratus & 2 & Pl. & & $\bullet(2)$ \\
\hline & Neoscortechinia sp. & 2 & Pl. & $\bullet(2)$ & \\
\hline \multirow[t]{5}{*}{ Fagaceae } & Castanopsis sp. & 5 & Pl. & $\bullet(4)$ & $\bullet(1)$ \\
\hline & Fagaceae & 1 & Pl. & $\bullet(1)$ & \\
\hline & Fagaceae querqus & 2 & P1. & & $\bullet$ \\
\hline & Lithocarpus sp. & 12 & P1.; S & •(1 Pl.; $10 \mathrm{~S})$ & - (1 Pl.) \\
\hline & Quercus sp. & 1 & Pl. & & $\bullet(1)$ \\
\hline Gesneriaceae & Gesneriaceae & 1 & Pl. & & $\bullet(1)$ \\
\hline
\end{tabular}


Imawan Wahyu Hidayat et al. / Biosaintifika 9 (3) (2017) 513-522

\begin{tabular}{|c|c|c|c|c|c|}
\hline Hamamelidaceae & Distylium stellare & 1 & P1. & & $\bullet(1)$ \\
\hline Illiaceae & Illicium sp. & 4 & P1.; H & & $\bullet(3 \mathrm{Pl} . ; 1 \mathrm{H})$ \\
\hline Juglandaceae & Engelhardtia serrata & 7 & P1. & & • (7) \\
\hline \multirow[t]{13}{*}{ Lauraceae } & Actinodaphne sp. & 5 & P1. & $\bullet(1)$ & $\bullet(4)$ \\
\hline & Beilschmiedia sp. & 1 & Pl. & & $\bullet(1)$ \\
\hline & Cinnamomum javanica & 7 & P1. & $\bullet(2)$ & $\bullet(5)$ \\
\hline & Cinnamomum zeylanicum & 2 & $\mathrm{P} 1 . ; \mathrm{H}$ & & $\bullet(1 \mathrm{Pl} . ; 1 \mathrm{H})$ \\
\hline & Cryptocarya sp. & 4 & P1. & $\bullet(1)$ & $\bullet(3)$ \\
\hline & Endiandra sp. & 2 & P1. & $\bullet(1)$ & $\bullet(1)$ \\
\hline & Lauraceae & 1 & P1. & & $\bullet(1)$ \\
\hline & Lindera sp. & 1 & P1. & & $\bullet(1)$ \\
\hline & Litsea lanceolata & 2 & P1. & & $\bullet(2)$ \\
\hline & Litsea sp. & 6 & P1. & $\bullet(2)$ & • (4) \\
\hline & Neolitsea sp. & 1 & Pl. & & $\bullet(1)$ \\
\hline & Persea sp. & 1 & Pl. & & $\bullet(1)$ \\
\hline & Phoebe sp. & 4 & Pl. & $\bullet(2)$ & $\bullet(2)$ \\
\hline Lycopodiaceae & Lycopodium sp. & 1 & P1. & & $\bullet$ \\
\hline Magnoliaceae & Magnolia sp. & 12 & P1.; C & • (1 Pl.) & • $(6 \mathrm{Pl} . ; 5 \mathrm{C})$ \\
\hline Melastomataceae & Medinilla sp. & 1 & Pl. & $\bullet(1)$ & \\
\hline Meliaceae & Meliaceae & 2 & P1. & $\bullet(2)$ & \\
\hline Monimiaceae & Kibara sp. & 2 & Pl. & $\bullet(2)$ & \\
\hline Moraceae & Arthocarpus sp. & 2 & P1. & $\bullet(2)$ & \\
\hline \multirow[t]{2}{*}{ Myristicaceae } & Gymnacranthea sp. & 1 & P1. & $\bullet(1)$ & \\
\hline & Myristica sp. & 1 & Pl. & & $\bullet(1)$ \\
\hline Myrsinaceae & Embelia sp. & 1 & P1. & & $\bullet(1)$ \\
\hline \multirow[t]{3}{*}{ Myrtaceae } & Rhodamnia cinerea & 1 & Pl. & $\bullet(1)$ & \\
\hline & Rhodamnia sp. & 1 & Pl. & & $\bullet(1)$ \\
\hline & Syzygium sp. & 15 & Pl. & $\bullet(4)$ & $\bullet(11)$ \\
\hline Nepenthaceae & Nepenthes sp. & 24 & P1. & - $(24)$ & \\
\hline Oleaceae & Olea sp. & 3 & Pl. & & $\bullet(3)$ \\
\hline \multirow[t]{14}{*}{ Orchidaceae } & Agrostophylum sp. & 1 & Pl. & $\bullet(1)$ & \\
\hline & Appendicula sp. & 5 & Pl. & & $\bullet(5)$ \\
\hline & Bulbophyllum armeniacum & 1 & Pl. & & $\bullet(1)$ \\
\hline & Bulbophyllum sp. & 3 & Pl. & $\bullet(3)$ & \\
\hline & Chelonis sp. & 1 & P1. & & $\bullet(1)$ \\
\hline & Coelogyne sp. & 2 & P1. & $\bullet(1)$ & $\bullet(1)$ \\
\hline & Dendrobium sp. & 7 & Pl. & $\bullet(4)$ & $\bullet(3)$ \\
\hline & Dendrochilum sp. & 3 & P1. & & $\bullet(3)$ \\
\hline & Dilocia sp. & 1 & P1. & $\bullet(1)$ & \\
\hline & Eria sp. & 13 & Pl. & $\bullet(4)$ & $\bullet(9)$ \\
\hline & Grammatophylum sp. & 2 & $\mathrm{Pl}$. & $\bullet(2)$ & \\
\hline & Liparis sp. & 2 & P1. & - $(2)$ & \\
\hline & Orchidaceae & 6 & Pl. & $\bullet(6)$ & \\
\hline & Phreatia sp. & 1 & Pl. & & $\bullet(1)$ \\
\hline
\end{tabular}


Imawan Wahyu Hidayat et al. / Biosaintifika 9 (3) (2017) 513-522

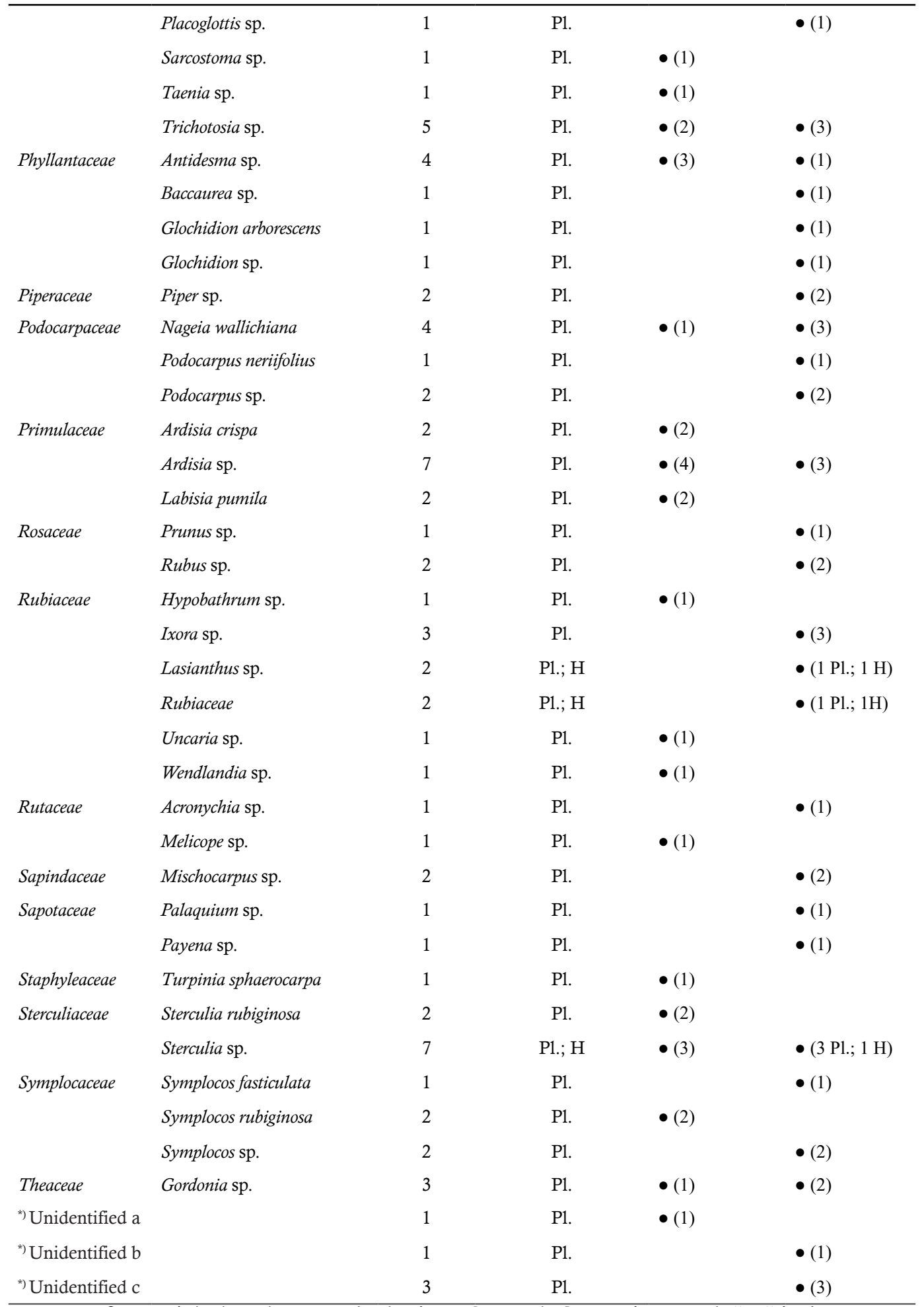

Note: Type of material $\mathrm{Pl} .=$ plant; $\mathrm{H}=$ herbarium; $\mathrm{S}=$ seed; $\mathrm{C}=$ cutting; mark " • "is the presence of species when its collected; bracket after mark " " is the amount of specimen and type of collection.

Myrtaceae, Podocarpaceae, Symplocaceae and Theaceae were also located at an elevation from 800 to more than $1,000 \mathrm{~m}$ asl.

Based on the field observation, it appears that the restriction zone based on elevation for vegetation classification was becoming narro- wer and lower than usual. It causes plant species which generally only could be found in the high mountains, could be found at an elevation which relatively low, or vice versa. As comparison, based on Shi and Li (2010) study on a species of the genus Dipterocarpus (Dipterocarpaceae) sho- 
wed that that species is distributed widely across habitats ranging from seasonal tropical wet forests at one extreme, to dry deciduous subtropical forests. Present day distribution reveals that Dipterocarpus individuals are numerically far more abundant in the dry deciduous and seasonally dry evergreen forests than their co-generic counterparts in the warmer wet forests of the equatorial tropics. Even though, the genus, and indeed the Dipterocarpaceae family as a whole, undoubtedly achieves its highest species richness in the seasonal wet tropical forests of Borneo, Sumatra and Peninsular Malaysia, but the genus is not, as indicated by Shi and Li (2010), a "classic Asian tropical rainforest indicator" (Ghazoul, 2012). Another facts had also revealed that Mount Seblat which located approximately at the earth's equator had a tropical climate and tends to be warmer despite at an elevation above 1,000 $\mathrm{m}$ asl with daytime temperatures can reach about $35-40{ }^{\circ} \mathrm{C}$ (based on field measurement). So, the species which were common in lower elevation still able to grow well in a higher location.

\section{Ex situ conservation effort}

Plants which have been collected subsequently sent to CBG for being cultivated (Figure 3 ). In order to ensure the survivorship level, the seedling houses were constructed at CBG to avoid direct exposure to sunlight and rain, and also keeping the moisture and reduce evaporation. Plant conditions were monitored daily by paying attention to the condition of planting media, fertilizing, watering and doing the pest and disease management, as well as the ability of the growth and development.

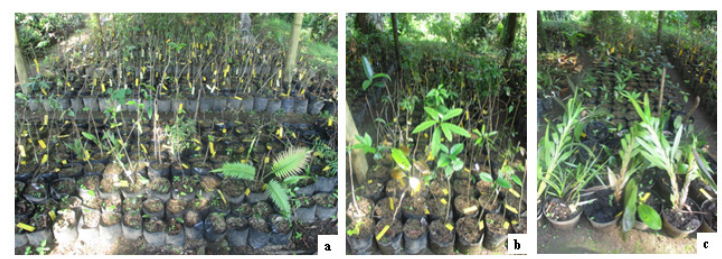

Figure 3. Condition of plants material after eight months maintenance (December $23^{\text {th }}, 2015$ ) in CBG: (a) the entirety collection; (b) seedling which is dominated by trees type (e.g. Symplocos fasticulata, Canarium sp., Orophea sp., Glochidion sp., Parashorea sp.); (c) seedling which is dominated by orchids and shrubs (e.g. Dendrochilum sp., Bulbophyllum armeniacum, Trichotosia sp., Rhapis sp., Staurogyne sp.). (Photographs by: Imawan W. Hidayat).

Based on December $23^{\text {th }} 2015$ data, after eight months of maintenance the percentage of collection survivorship reached 65\% accumulatively, or proportional of death rate was $35 \%$ (133 specimens were death). This means that 247 specimens of plants collection were survived and could be lived and thrived (Figure 4). This survivorship level was still considered within the normal limits, considering that the micro climatic conditions and bio-physical factors in CBG is not exactly the same as the conditions on Mount Seblat.

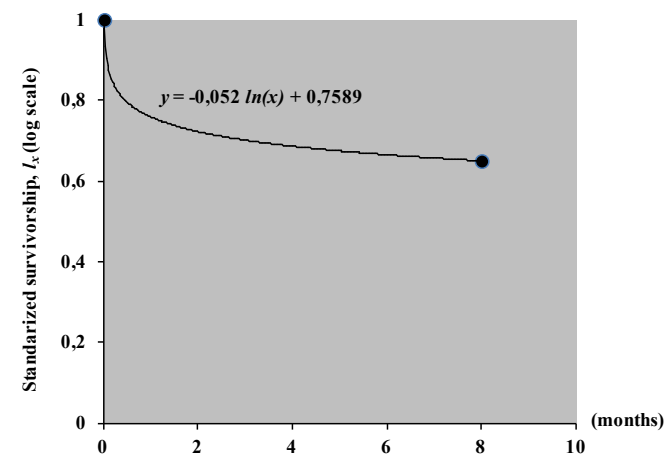

Figure 4. Survivorship curve of plants collection after eight months maintenance (December $23^{\text {th }}$, 2015). Note: $n=$ number of survival plants; $t$ : time or plants age.

Based on the Figure 4, the survivorship level of the collection includes in type III, which means that the mortality at early stage or juvenile is high and life expectancy increases for individuals who survive their risky juvenile period (Dash \& Dash, 2009; Cain et al., 2013; Smith \& Smith, 2014; Molles, 2015). At the first two months, plants were suffered a high mortality, but then at next periods the mortality level is gradually decreased. At this stage, the plants were trying to adjust to new surroundings after being removed from their habitat. The differences of microclimate and biophysical conditions between previous habitat to a new environment in CBG influence on the survival rate of these plants.

Nevertheless, the optimization efforts to maintain the survival of the remains collection will be continued. Watering, fertilizing, providing the vitamin and pest control will be routinely performed, either daily or weekly. So, hopefully with the routine maintenance and the increasing age of the plant, then the survival rate can be increased. The plants collection will remain at seedling house of CBG until a later conservation ex situ unit be ready to register the plants to be planted in the garden.

These efforts and study have made a real contribution in the context of ex situ conservation of plants, especially Sumatran mountain plants. 
Besides providing an overview of the inventory of plant diversity, the collected plant maintenance activities provide a living plants specimen which can be studied further, both on the type, potential usefulness and further utilization (Abdullah et al., 2010; Murdjoko et al., 2016). When plants can be planted in the garden and displayed, the collection will add value in the interest of education and research, and knowledge dissemination for sciences and public.

\section{CONCLUSIONS}

Mount Seblat, as a part of KSNP, was still reserve a high biodiversity, especially plant species. As a tropical wet highland in Sumatra, Mount Seblat had various endemic plants which are typical of tropical wet highlands. Although including to montane zone, plant diversity of Mount Seblat which discovered was frequently overlap. These apparently caused by the tropical climate which gives a very strong influence on environmental conditions. These studies has succeeded to initially conduct and inventory of plant diversity of Mount Seblat and collected lo$\mathrm{cal}$ characteristics of living plant specimens. The maintenance and propagation process have also resulted significant number of survived plants. Next, these plants were new living collection of CBG which increase the value of plants ex situ conservation and knowledge dissemination, especially for education, and research interest to scientific society and for public. Therefore, this plants ex situ conservation was hopefully providing more value added to the protection of biodiversity, not only in preservation but also for further research of these usefulness for life.

\section{ACKNOWLEDGEMENTS}

This study was entirely funded by DIPA Tematik of Indonesian Institute of Sciences (LIPI) fiscal year of 2015 by code 079.01 .06 .3396 .002 .020 . A . Our grateful towards the Kerinci Seblat National Park (The Ministry of Environment and Forestry of Republic of Indonesia), especially to Division III Curup-Rejang Lebong, Mr. Ismanto, Mr. Jonathan Hiskia Sinuhaji, Mr. Pestu Doben, and other staffs. Our grateful was also wish towards Mr. Arwin Arapik, which had been accompanied during field activities and to community of Seblat Ulu Village, especially to Mr. Roni A. Ramadhani and Mr. Ahmad Buhari.

\section{REFERENCES}

Abdullah, M., Mustikaningtyas, D., \& Widiatningrum, T. (2010). Inventarisasi Jenis-Jenis Tumbuhan Berkhasiat Obat di Hutan Hujan Dataran Rendah Desa Nyamplung Pulau Karimunjawa. Biosaintifika: Journal of Biology \& Biology Education, 2(2), 75-81.

Aitken, S. N., \& Whitlock, M. C. (2013). Assisted gene flow to facilitate local adaptation to climate change. Annual Review of Ecology, Evolution, and Systematics, 44, 367-388.

Bettinger, K. A. (2014). Political contestation, resource control and conservation in an era of decentralisation at Indonesia's Kerinci Seblat National Park. Asia Pacific Viewpoint, 56(2), 1-15.

Braverman, I. (2014). Conservation without nature: the trouble with in situ versus ex situ conservation. Geoforum, 51, 47-57.

Broadhurst, L. M., Lowe, A., Coates, D. J., Cunningham, S. A., McDonald, M., Vesk, P. A., \& Yates, C. (2008). Seed supply for broadscale restoration: maximizing evolutionary potential. Evolutionary Applications, 1(4), 587-597.

Brummer, E. C., Barber, W. T., Collier, S. M., Cox, T. S., Johnson, R., Murray, S. C., Olsen, R. T., Pratt, R. C., \& Thro, A. M. (2011). Plant breeding for harmony between agriculture and the environment. Frontiers in Ecology and the Environment, 9(10), 561-568.

Butler, R. A., Koh, L. P., \& Ghazoul, J. (2009). REDD in the red: palm oil could undermine carbon payment schemes. Conservation Letters, 2(2), 6773.

Cacho, O. J., Milne, S., Gonzalez, R., \& Tacconi, L. (2014). Benefits and costs of deforestation by smallholders: Implications for forest conservation and climate policy. Ecological Economics, 107, 321-332.

Cain, M. L., Bowman, W. D., \& Hacker, S. D. (2011). Ecology. 3th Ed. Massachusetts: Sinauer Associates, Inc.

Dash, M. C., \& Dash, S. P. (2009). Fundamentals of Ecology. $3^{\text {th }}$ Ed. New Delhi: Tata McGraw Hill Education Private Limited, pp, 248-250.

Ghazoul, J. (2012). The challenge of inferring palaeoclimates from extant plant distributions: An example from Dipterocarpus. Review of Palaeobotany and Palynology, 173, 80-81.

Koh, L. P., \& Wilcove, D. S. (2008). Is oil palm agriculture really destroying tropical biodiversity? Conservation Letters, 1(2), 60-64.

Laumonier, Y., Uryu, Y., Stuwe, M., Budiman, A., Setiabudi, B., \& Hadian, O. (2010). Eco-floristic sectors and deforestation threats in Sumatra: identifying new conservation area network priorities for ecosystem-based land use planning. Biodiversity and Conservation, 19(4), 1153-1174.

Molles, M. C. (2015). Ecology: Concepts and Applications. $7^{\text {th }}$ Ed. New York: McGraw-Hill Education.

Murdjoko, A., Marsono, D., Sadono, R., \& Hadisusanto, S. (2016). Plant Species Composition and 
Their Conspecific Association in Natural Tropical Rainforest, South Papua. Biosaintifika: Journal of Biology \& Biology Education, 8(1), 33-46.

Neale, D. B., \& Kremer, A. (2011). Forest tree genomics: growing resources and applications. Nature Reviews Genetics, 12(2), 111-122.

Partomihardjo, T., \& Rahajoe, J. S. (2004). Pengumpulan Data Ekologi Tumbuhan. In Rugayah, Widjaja, E.A., Praptiwi. Pedoman Pengumpulan Data Keanekaragaman Flora. Bogor: Research Center of Biology.

Richards, C. M., Antolin, M. F., Reilley, A., Poole, J., \& Walters, C. (2007). Capturing genetic diversity of wild populations for ex-situ conservation: Texas wild rice (Zizania texana) as a model. Genetic Resources and Crop Evolution, 54(4), 837848.

Shi, G., \& Li, H. (2010). A fossil fruit wing of Dipterocarpus from the middle Miocene of Fujian, China and its palaeoclimatic significance. $R e-$ view of Palaeobotany and Palynology, 162(4), 599. 606.

Sniderman, J. M. K., \& Jordan, G. J. (2011). Extent and timing of floristic exchange between Australian and Asian rain forests. Journal of Biogeography, 38(8), 1445-1455.

Smith, T. M., \& Smith, R. L. (2014). Elements of Ecology. $9^{\text {th }}$ Ed. London: Pearson.

Surat Keputusan Ketua LIPI Nomor 23/Kep/D.5/87, tanggal 17 Januari 1987, tentang Organisasi dan Tata Kerja Lembaga Ilmu Pengetahuan Indonesia.

Surat Keputusan Menteri Kehutanan dan Perkebunan Nomor 901/Kpts-V/1999, tentang Penetapan dan Penunjukan Taman Nasional Kerinci Seblat.

Van der Werf, G. R., Dempewolf, J., Trigg, S. N., Randerson, J. T., Kasibhatla, P. S., Giglio, L., Murdiyarso, D., Peters, W., Morton, D. C., Collatz, G. J., Dolman, A. J., \& DeFries, R. S. (2008). Climate regulation of fire emissions and deforestation in equatorial Asia. Proceedings of the National Academy of Sciences, 105(51), 20350-20355.

Vitt, P., Havens, K., Kramer, A. T., Sollenberger, D., \& Yates, E. (2010). Assisted migration of plants: changes in latitudes, changes in attitudes. Biological Conservation, 143(1), 18-27. 